\title{
Geographies of heteroactivism: Resisting sexual rights in the reconstitution of Irish nationhood
}

\author{
Kath Browne $^{1}$ (D) | Catherine J. Nash ${ }^{2}$ | Andrew Gorman-Murray ${ }^{3}$ (D)
}

${ }^{1}$ Department of Geography, Maynooth University, Co Kildare, Ireland

${ }^{2}$ Brock University, St. Catherines, ON, Canada

${ }^{3}$ Western Sydney University, Penrith, NSW, Australia

Correspondence

Kath Browne

Email: Kath.browne@mu.ie

\section{Funding Information}

Government of Canada, Social Sciences and Humanities Research Council of Canada (Grant number: 435-2014-0071).
Legislative and cultural changes have produced significant shifts in sexual and gender rights. Although this has been extensively studied in relation to those who have "won" and in relation to the normalisations that these changes create, there is little scholarship on the emergence of new resistances to Lesbian, Gay, Bisexual and Trans equalities. We employ the term heteroactivism to name the ways that resistances to sexual and gender rights have moved from vilifying "the homosexual," towards more subtle and nuanced resistances in places with sexual and gender equalities legislation. Geography is key because legislation and its enactment varies spatially, and national legislations and imaginings recreate distinctive, place-based heteroactivism. Paying attention to the ideologies of those who opposed same-sex marriage in Ireland's 2015 referendum, this paper explores how the boundaries of Irishness were central to heteroactivist campaigns, drawing on specific invocations of relatedness between a female child and her mother, the quintessential Irish Mammy. Using a close reading of the textual and visual elements of a "Vote No" poster, the paper elucidates the presences and silences of new forms of resistances that seek to recuperate what was once not only "common sense" heterosexuality, but also seen as the essence of Irishness. In doing so, the paper extends understandings of sexuality-gender-nation-state nexus by critically interrogating the ideologies of those who contest progressive state sexual and gender legislation.

\section{K E Y W O R D S}

bisexual and trans, discourse and visual analysis, Gay, Ireland, lesbian, motherhood, nation, sexuality

\section{1 | INTRODUCTION}

There is little doubt that transformations in our sexual landscapes, including the advancement of gender and sexual rights, are one of the defining features of the 21st century. Our intimate and private relationships, sexual or otherwise, are not only vital to our everyday lives, but are often key to our (public) interactions with the state and public bodies (such as schools and health care providers), which often defines the ideal adult relationship within coupled terms (Wilkinson, 2013). An extensive scholarship has evolved around the significance of these legislative and social gains for sexual and gender minorities, as well as how these are spatially lived and experienced (Brown \& Browne, 2016). Far-reaching contestations have erupted over sexual (and gender) exclusions, including concerns about the narrowing of sexual and gendered expressions and related political and social practices captured under the rubric of homonormativity (Bell \& Binnie, 2000). Scholarship 
also highlights the homonormative ideologies that frame some states as "progressive" or "modern," or conversely to label others as "backward" and "traditional," thereby reflecting particular forms of homonationalism (Puar, 2007).

What remains less well understood are contemporary resistances to gender and sexual rights, including opposition to same-sex marriage in North America, the UK and the European Union. While opposition to sexual and gender equalities takes many forms, we argue that a particular mode of activism is becoming more prevalent, emerging in new, more inclusive sexual and gender landscapes. This activism involves the reification of particular forms of monogamous and coupled heterosexuality between normatively gendered men and women, portrayed as under threat through state-based legislative inclusions, such as same-sex marriage. We use the term heteroactivism to denote this emergent form of political and social activism - one that promotes heterosexualities as morally superior to other sexual/gender identities and social relations and as the "best for society" (see Browne \& Nash, 2014; Nash \& Browne, 2015). ${ }^{1}$ Our research emerges from and builds on scholarship examining resistances to so-called "gender ideologies" (Kuhar \& Paternotte, 2017), US-based studies on the activities of the "Christian Right" (Burack, 2014; Dowland, 2015) and other forms of resistance to Lesbian, Gay, Bisexual and Trans (LGBT) rights (e.g., Johnson \& Vanderbeck, 2014). Heteroactivist resistances signal a developing opposition to a perceived new social order that reflects the loss of hegemonic heteronormativities. Oppositional ideologies and modes of resistance have to adapt in places where the vilification of homosexuality and related "anti-gay" rhetoric is both ineffective and potentially sanctionable within state-based anti-discrimination legislation.

This paper argues that heteroactivism, in its quest to maintain or reinstate specific forms of heteronormativities, is inherently geographical in that heteroactivists (re)craft their arguments and practices within and through specific local and national contexts. Understanding the specific nature of these resistances in contemporary sexual landscapes pushes theorising in geographies about the constitution of contemporary nation-states through a sexual-gender nexus. Taking a geographical perspective enables a foregrounding of the mutual reconstitution of nation-state-gender-sexuality, ensuring that the social is not hierarchised over the spatial (Hubbard, 2006). We argue that heteroactivism assumes distinctive spatial configurations that are networked in and through place, creating specific geographies of heteroactivism that in turn reconstitute sexual (and gendered) landscapes.

To develop these arguments, we examine the form and substance of heteroactivism in Ireland in the lead up to the vote on same-sex marriage on 22 May 2015. Following an overview of contemporary scholarship on resistances to gender and sexual rights, the paper turns its attention to Ireland and the gender and sexualities of nationhood. Examining the underpinning ideologies of the "Vote No" campaign, the paper draws critical attention to how geographies not only infuse but reconstitute political activities and discourses of organisations opposed to same-sex marriage (and arguably gender and sexual rights broadly). We explore the creation of heteroactivist ideologies as they emerged in and through "modern Ireland" and in the debates about "who is Irish." This not only begins the important project of conceptualising heteroactivism in geographical terms; it elucidates how geographical specificities and national imaginings are crucial to our understandings of the contours of emerging gender and sexual landscapes in places where state-based sexual and gender rights are seen to be "won."

\section{2 | CONTEMPORARY RESISTANCES TO GENDER AND SEXUAL RIGHTS EQUALITIES}

Sexualities are a significant subdiscipline in Geography, investigating the centrality of sexual and gendered lives and experiences in formations of everyday spaces, national imaginaries and citizenships, as well as transnational interrelationships. Initially, scholarship focused on the creation of space as heterosexual, challenging the assumption that space was asexual unless constituted as the space of homosexuals, sex workers and other "deviancies" (Bell \& Valentine, 1995). More recently, in light of legislative and cultural gains for sexual and gender minorities, scholarship has taken a "homonormative turn," interrogating how new sexual and gendered landscapes can recreate normalisations, and recuperate classed, racialised and gendered norms (Brown \& Browne, 2016). Explorations of resistances to LGBT rights are largely absent in Geography, with much of the research taken up in Political Science, which explores the Christian Right and conservative oppositional activism - perhaps the most well-known organisations resisting LGBT equalities (e.g., Andersen \& Fetner, 2008; Burack \& Wilson, 2009; Rayside \& Wilcox, 2011; Tremblay et al., 2011). ${ }^{2}$ This research contributes to a broader literature on the political and social activism of the Christian Right, dominated by a focus on experiences in the USA (for instance, Burack \& Josephson, 2005; Todd \& Ong, 2012).

As we have argued elsewhere, locating heteroactivism solely within either Christianity or in the right-wing element of the political spectrum is problematic (Browne \& Nash, 2014). Such a focus overlooks the geographical and temporal 
specificities of oppositional organisations, thereby negating the distinctive and contextual ways these resistances take shape (see Maddox, 2014). Research suggests that oppositional groups encompass, but are not limited to, religious resistances including the Catholic and Anglican churches (Johnson \& Vanderbeck, 2014; Kuhar \& Paternotte, 2017), which entangle the state as well as various conservative and "traditionalist" organisations (Browne \& Nash, 2014; Nash \& Browne, 2015).

Resistances to sexual and gender equalities are also visible in challenges to progressive states through legislative contestations, which pit religious (read Christian) freedom against sexual and gender rights (e.g., Stychin, 2009). State-based recognition goes beyond legislation and is also embodied in those who enact the state's policies. Thus, contestations regarding the provision of services to LGBT people by state employees highlight how views that were once in line with those of the state are now resisting legislative imperatives (Cooper, 2015). The entwining of religion-state-sexuality can be seen through the practices of those who (refuse to) enact progressive policies. Moving from the state to the recent emergence of far-right nationalism, it is important to query the essentialised links between those opposed to gender and sexual rights and far-right nationalism. Evidence suggests that nationalist populism and far-right ideologies can both embrace and reject sexual and gender rights (e.g., Siegel, 2017).

These for/against models of reading resistances to gender and sexual equalities overlook how heteroactivists can be ostensibly supportive of certain sexual and gender rights in order to distance themselves from accusations of homophobia. In Canada and Great Britain, both locations with strong sexual and gender equalities, new heteroactivist politics have moved from vilifying homosexuals and diminishing their families to focusing on arguments about the best interests of society and children (Nash \& Browne, 2015). Often in these debates, heteroactivists actually frame their arguments as ostensibly "supportive" of LGBT families and relationships, but only conditionally. For example, Browne and Nash (2014) highlight how civil partnerships in Great Britain were overtly supported by groups that opposed same-sex marriage, arguing that civil partnerships were "enough." Thus, there are overlaps between those who are "supportive" of certain LGBT rights (e.g., civil partnerships) in order to halt the progression of other forms of sexual and gendered rights (e.g., same-sex marriage). Particular forms of homonationalism and heteroactivism sometimes overlap, where the rights gained by sexual minorities are "enough" and illustrate the "progressiveness" of the nation/political party/individual and are used to "defend gay people" from (often Muslim) others. ${ }^{3}$

In turning our attention to the marriage debate in Ireland and particular forms of Irish nationalism, we shift focus away from accounts of oppositions modelled on the USA historical experience to consider contemporary manifestations of resistances to gender and sexual equalities. This does not take these resistances as merely being exported from the USA, but ensures we focus on how these resistances emerge within specific local, regional and national conflicts and contexts (Kuhar \& Paternotte, 2017). This offers a much-needed, geographically nuanced investigation into how oppositions to sexual and gender rights emerge, circulate and are grounded in differing places (Browne \& Nash, 2014; Kuhar \& Paternotte, 2017; Nash \& Browne, 2015).

Same-sex marriage is a key political, social and legislative achievement through which sexual citizenship has been, and continues to be, contested, negotiated and reformed (e.g., Bell \& Binnie, 2000; Harding \& Peel, 2006). The majority of the literature on same-sex marriage critically explores the benefits and normalisations gained through the implementation of same-sex marriage activism. On one hand, decades of writing challenges the arguments put forward by those against samesex marriage, often drawing on liberal viewpoints that regard same-sex marriage (and assimilation more broadly) as advancing the rights of lesbians and gay men (e.g., Rauch, 2004). Conversely, an alternative scholarship argues that same-sex marriage results in the exclusion of some sexual and gender minorities from claims to recognition/citizenship (e.g., Richardson, 2004, 2005). ${ }^{4}$ While it is important for geographers, and others, to examine the implications of same-sex marriage and new homonormalisations that can recuperate systematic marginalisations, including those related to race, class, gender and relationships, scholars also have a key role to play in exploring heteroactivism more broadly. Geographers have a significant role in refusing theories of homo- or hetero-normativities that fail to account for how these arguments are developed through and in places, and in this case, national imaginaries.

\section{3 | SEXUALITIES AND GENDERED NATIONHOOD IN IRELAND}

A nation and its citizenry are constituted through the reification of certain (often hetero) sexualities (and normative genders). An important body of feminist literature shows how national ideologies suffuse everyday lives in ways that both include and move beyond local and state governance and that nations are mapped and represented in gendered and sexual terms (e.g., Mayer, 2000; Nash, 1993, 1994). A parallel scholarship argues that hegemonic heteronormativities are core to the construction of national identities (Bell \& Binnie, 2000; Nast, 2002). More recently, the hegemonic heterosexualities of 
nations has come into question through the concept of homonationalisms, that is, the use of "gay rights" to support forceful nationalist and military agendas (Puar, 2007).

Ireland is an easy fit for turn-of-the-century theorising regarding the engrained heteronormativity of nation states. Irishness in the 20th century gave the family "pride of place" in the reproduction of the Irish nation (Greene, 1994, p. 357). Not only did British colonialism distance homosexualities from itself, so too did Irish nationalism (Conrad, 2001, 2004). Catherine Nash's explorations illustrate the complexities of the gendered and sexualised construction of Irish nationhood created through a postcolonial context (Nash, 1997). Nash's examinations of genetics and belonging in the Irish nation-state posed the central question of "Who counts as Irish?", which is always constructed through specific constellations of power relations (Nash, 2008). Whereas these power relations once excluded "the homosexual" as "not Irish," contemporary sexual/gendered power relations have reconstituted Irish sexualities and genders. "Who counts as Irish?" now needs to account for the significant strides Ireland has taken in the legal, social and cultural recognition of LGBT rights (e.g., Connolly, 2014; Neary, 2016), as well as for divorce, contraception and potentially abortion rights. Both domestic and international factors have also meant a "speedy process of political change" (Neary, 2016, p. 758). These factors include a weakened Catholic Church due to sex abuse scandals and a resulting turn to secularism, membership in the EU and associated legal equalities reforms, and a growing economy in the 1990s (until the economic crisis in 2008) which resulted in both return and increased immigration (McAuliffe \& Kennedy, 2017; Ryan, 2015). In 2010, civil partnerships for same-sex couples became law and on 22 May 2015, after a bitter campaign, Ireland voted yes to a constitutional change making marriage genderless, 20 years after Ireland decriminalised homosexuality in 1995.

\section{1 | Same-sex marriage referendum}

Any amendment to Ireland's Constitution requires a referendum, and there have been referenda on social issues such as divorce (passed narrowly in 1995) and abortion (still illegal on the entire island of Ireland and the subject of a referendum expected in 2018). ${ }^{5}$ Because of this constitutional requirement, Ireland was the first country to hold a national referendum on same-sex marriage to create a 34th amendment that would alter Article 41 of the Constitution (see Ryan, 2015 for full constitutional details). Irish citizens eligible to vote were asked to consider the question: "Do you approve of the proposal to amend the Constitution contained in the undermentioned Bill?" The proposed amendment would alter the constitutional statement on marriage to read: "Marriage may be contracted in accordance with law by two persons without distinction as to their sex."

All the main political parties supported a Yes vote. $1,949,725$ people $(60.52 \%$ of electorate) voted in the referendum with $62.07 \%$ voting Yes (1,201,607 people) and 37.93\% voting No (734,300 people) (Referendum Results, 2015). Reports indicated that many people travelling abroad also returned to Ireland to vote. While many articles explored the nuances and normalisations of the arguments presented for the "Yes" vote and what this means for Ireland (e.g., Mulhall, 2015; Neary, 2016; Ryan, 2015; Silvera, 2015), this paper focuses on the arguments deployed to persuade almost three-quarters of a million people to vote "No." In doing so, it illuminates how state-based legislation evoked the contestations of the "new" sexualities and genders of the nation. These challenges were embedded in supposedly "reasoned" and "common sense" arguments marking a particular form of heteroactivist geography. These power relations not only provide insight into resistances to sexual and gendered rights, but also to the expanding definition of Irishness, which for so long created heteronormative boundaries both within the state and beyond (Conrad, 2001; Nash, 1997).

\section{2 | Gendering Irishness}

The heteronormative boundaries of Irishness are gendered in very specific ways. Gender is crucial to engaging with heteroactivism, because it is the basis on which sexualities are premised. Gender is central to the Irish nation's symbolic reading of itself as female and to the motherly figure of Eire (Stevens et al., 2000; Thapar-Björkert \& Ryan, 2002). The place of the Irish woman in the home was inscribed into the second constitution in 1937 after the Republic of Ireland became independent from the United Kingdom in 1922. This was in part to establish a masculine national identity that contrasted with the feminisation of Ireland under colonial rule (Martin, 1997, 2000; Ryan-Flood, 2005). The paragraph of the Irish Constitution to this day reads:

The State recognises that that by her life within the home, woman gives to the State a support without which the common good cannot be achieved.... The State shall, therefore, endeavour to ensure that mothers shall not be obliged by economic necessity to engage in labour to the neglect of their duties in the home. 
Clearly, not only are women's bodies regulated by Irish nationhood, but women's place is written into the Constitution (see also Crowley \& Kitchin, 2008). This is not to suggest a passive femininity, because as Kearns (2004) notes, passive representations of Irish women are at odds with their practical involvements, thereby contesting their exclusion from the public spheres. Martin (2000, p. 81) contends there is a gendered labouring of nationalism reflecting an enduring influence on Irish women's everyday lives. This labour is placed in the home and the figure of the woman is a mother in the home; she is key to what it is to be Irish (Meaney, 1994). In an ironic way, the private sphere of the home is "at the same time core to the very public symbolic image of Ireland as "mother', and the nation as "family"" (Wills, 2001, p. 37). This placing of women at the "heart of the home" and the image of Ireland has not disappeared, and Negra (2014) argues that "abiding mammies" have been key discourses in post-2008 austerity Ireland. The "common good" is also a key trope used by heteroactivists to reinforce the attachment of family, marriage and child-rearing to heteronormative coupledom (see Browne \& Nash, 2014; Nash \& Browne, 2015). In the Irish context, this once again places heterosexual and procreative women into the role of defending the nation's moral values (see also Martin, 2000). The idealised Irish woman, as is the case with many national projections of womanhood, is a chaste one (Nash, 2008). Who is Irish? is simultaneously and inseparably gendered and sexualised.

It is clear, then, that the Irish context offers fertile ground to explore how heteroactivism is made manifest through the state-nation-sexuality-gender nexus. Following a discussion of methods, we undertake a close reading of one of the posters used in the Vote No campaign, enabling us to disentangle key ideological structures underpinning it. What this analysis demonstrates is that heteroactivism is constituted through gender and sexual normativities, and that these are created in and through national (and expressly geographical) contexts.

\section{4 | METHODS}

Our analysis of this poster draws on recent geographical engagements with visual and socio-linguistic methods of analysis, specifically combining visual and textual analysis (e.g., Rose, 2016; and the ACME special issue on Queer Semiotics 2017). We use these methods to explore the importance of the visual and textual in place-making, emphasising how they inform everyday lives and material realities. In queer semiotics, which draws on socio-linguistic methods, the study of language allows insight into discourses that reconstitute sexualities and genders, and is associated specifically with identities (see Zebracki \& Milani, 2017). While not all texts and visuals gain prominence, some become associated with a movement. Because they are socio-linguistic, images and texts do more than represent, they (re)create messages, ideals and ideologies. Further, a solely textual analysis of key arguments could overlook crucial visual markers such as campaign posters that became visible in public spaces in the run up to the referendum vote (see Mulhall, 2015).

Focusing on a poster enables an examination of public messages within and beyond media outlets. Seeking to try to convey an unambiguous cultural and political point of view, the poster's messages were intended to be didactic and closed, not speculative and open (Robertson \& McDaniel, 2010). Critically, such campaign posters are embroiled in competing discourses about cultural norms, national belonging and webs of relatedness. By not inviting questioning, they offer insights into the closed message and its underpinning tenets. Focusing on the Vote No campaign, we can work through how such messages were managed and offer insights into geographies of heteroactivism, namely the underpinning ideologies that are inherently spatial.

The poster chosen for this paper (Figure 1) ${ }^{6}$ is part of a series of three posters released in April 2014 and placed on lampposts around Ireland, two of which dealt with mothers and one that argued that civil partnerships were "enough" (see O'Caoimh, 2015). The poster was chosen from this series in part because of the reaction and coverage it received, including newspaper articles (e.g., Kearns, 2015). This poster "raised ire" as some viewed it as insulting to non-biological parents ${ }^{7}$ while also keeping surrogacy in the debate, even though the government can still legislate around surrogacy. ${ }^{8}$ The poster was also the focus of social media discussion (e.g., Entertainmentwise, 2015) showing its reach online as well as offline.

Figure 1's visual and textual impact was also a key factor in this choice. An analysis of the poster offers new insights into the geographies of heteroactivism not only because it laid bare many of the key components of the Vote No campaign, but also because it visually represented resistances to sexual and gender rights in an era where overtly naming homosexuality as deviant is no longer viable. Visually or textually referencing positions that are unsayable makes them an absent presence both simultaneously silent and visible. These spectres are crucial and often difficult to contest because they are easily deniable as "your interpretation." Thus, a critical discursive reading of the visual and linguistic composition of this poster does more than engage with articulated ideologies - it allows an interrogation of visual/textual presences that create discursive silences. 


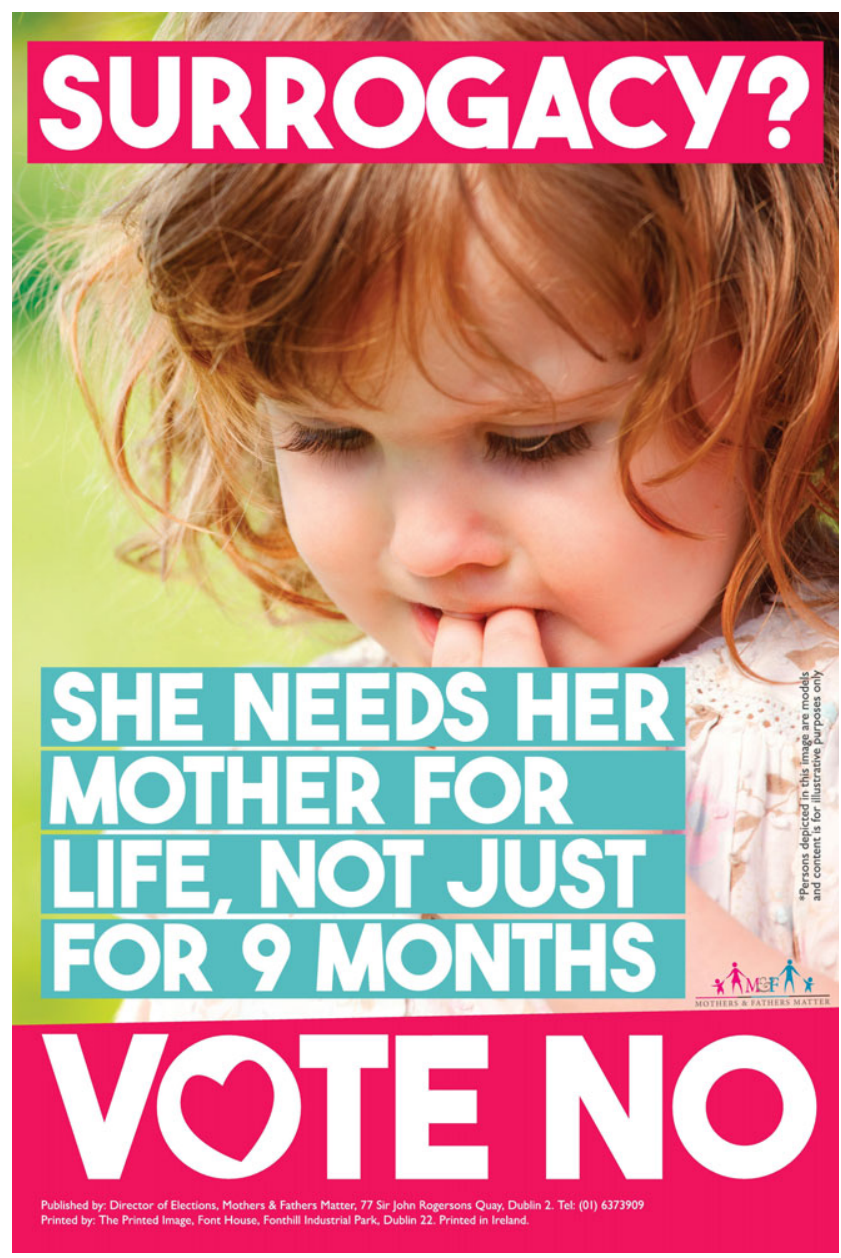

FIGURE 1 Vote No poster.

Source: Reproduced under Creative Commons [Colour figure can be viewed at wileyonlinelibrary.com]

Visual language, while powerful in its own right, is usually accompanied by text, with the images and words juxtaposed and working symbiotically to convey an intended meaning (Rose, 2016). Our analysis took these elements in tandem, creating an examination of the simultaneous visual and textual language used evocatively to assert ideological views. In addition, we took various elements that made up the visual and textual to explore how the complete picture was created. Consequently, the visual and socio-linguistic analysis was conducted through a close reading of the image, examining the overall message and then examining each word to explore the key discursive message and make explicit the underpinning ideologies. For the visual analysis, the elements selected included the nature of the actor chosen and the composition of the picture. This was then co-read with the text, where each word and punctuation mark was deconstructed in detail to explore both presences and silences.

Themes initially emerged from the visual/textual analysis of the poster itself, and developed through writing out their meanings and linking this to other research, literature and concepts. Moving back and forth slowly and carefully between the poster and literature, our analysis gradually layered together the arguments of this paper. This was augmented by comments on presentations and drafts of this paper that further pressed key analytical points.

In undertaking a critical discursive reading of the Vote No campaign poster, we are able to render explicit the resistive messages it broadcasts. We augment this with broader work on heteroactivist organisations, namely following organisations, their media and web presence and the activities they engage in. This allows us to investigate and tease out the geographies of heteroactivist organisations, offering insights into discursive regimes of gender/mothers and the family/sexualities that reframe the nation-state-sexuality-gender nexus in new gender and sexual landscapes. There are of course limitations to this (and every) method, and the focus on a close reading of the poster does not allow for engagement with how it was read, resisted and incited action (such as gathering allies through alienating all who might have fertility support needs). 


\section{5 | VOTE NO: SURROGACY AND MOTHERHOOD}

Drawing on the figure of the mother and focusing on her children, a key heteroactivist tactic on opposing same-sex marriage in Ireland was to argue that it was detrimental to the nation, society and the "common good." These heteroactivist discourses relied on key underpinning tropes, which are unpacked in this section: (1) the figure of an innocent Irish child" (2) in need of protection from (3) predatory gay men for the (4) good of the nation/common good and the future. This protection is (5) centred on and created through a mother (singular), (6) central to a "real"/"proper" family (7) who embodies (8) genetic relatedness and (9) an idealised mother-daughter relationality. This creates and sustains a (10) natural order that is based on (11) love for the nation/child/family. Examining how these were formed through textual and visual pointers and cues, we demonstrate how the intertwined constitution of nation-state-gender-sexuality (re)creates hegemonic heteronormativities through heteroactivist ideologies.

Figure 1 depicts a female child with two of her fingers in her mouth, looking down with a contemplative and perhaps unhappy expression. Wavy hair frames her face. The choice of a female child and the intentional innocence and pensiveness of the pose speak to the child's vulnerability and need for protection by suitable adults. The common sense visual representation of an "Irish child" resides in white skin (also used by the Yes campaign to appeal to middle Ireland; Mulhall, 2015), the slight red tinge to her hair and the clothes chosen to indicate a recognisable (and class respectable) Irish heritage rendering her one of "our" children. Whiteness is crucial to Irishness, and is tied into the rejection of others in order to recreate national selves (McVeigh, 2010; Walter, 2001). In Ireland, the foreign other/pollutant, both in terms of Irish nationalism and British colonialism, has previously been the overt and visible figure of "the homosexual." This figure provokes both disgust and the need to be distanced from Irishness both in Ireland and abroad, for example, through St Patrick's Day parade bans on gay and lesbian marchers who could not be "truly Irish." The foreign other is not only sexualised through nationalism, the homosexual becomes foreign through a sexuality that cannot be Irish (Conrad, 2001, 2004). It is not just the figure of $a$ child that is disrupted by same-sex marriage, this image lays claim to the figure of a particularly Irish child whose innocence and safety must be protected. The threat is no longer a foreign homosexual individual and the protector the state, the state enabled through a Yes Vote would become the threat in a new era of sexual rights, embodied through same-sex marriage.

Ireland has long been idealised as a "good place to bring up children," where national pride can be an important element, alongside the place of and support for the family (Greene, 1994). This feeds into the "nation-as-family" discourse, which is opposed to the "alienated and bullish British state" (Wills, 2001, p. 38). The visual discourse of the Irish child helps heteroactivists lay claim to the territory of protector of the nation's children, moving beyond one child to all children, and also to the experiences of Irish childhood itself. In this case, mothers create a white, Irish future, ensuring girls are protected from "the homosexual as the foreign at home" through appropriate parental and familial relationships to create the "right kind" of Irish childhood (Conrad, 2001, p. 127).

Surrogacy? A second discourse pertains to the child created through surrogacy whose life is "less" than those produced through marriage within a heterosexual family and whose validity is evidenced by the presence of biological children. ${ }^{10}$ Surrogacy was a key flashpoint used to signal the "dangers" of same-sex marriage. The image of this quintessential Irish child is overlaid with large text. First, and beginning at the top of the image, is the title "Surrogacy?" As the opening gambit, this title conjures up an alternative discourse that is juxtaposed with the visual image of the innocent Irish child. It is a familiar trope of the predatory man, or in this case gay men looking to exploit vulnerable women to bear their children (Nast, 2002).

The discourse of Surrogacy intimated the supposed risk of a child having two male parents, not only in terms of what is lacking, but also the dangers they supposedly posed to "vulnerable women and children." Given that men cannot biologically reproduce without access to eggs and uteri, this discursive move gestured to the unnaturalness associated with surrogacy, as well as the lack of at least one male parent's clear genetic link to the resulting child. Genetic links are key to creating (heteronormative) families and the webs of relatedness formed through power and sexual politics create a hegemonic form of genealogical connection (Nash, 2008) that is threatened by reproductive technologies (Nash, 2005). Because of the supposed biological connections to who is Irish, this raised core disputes that pitted the "traditional" family (read heteronormative, procreative; Conrad, 2004) against emerging modern families (a distinction often also played out in terms of abortion and membership to the "modernising EU") (Coulter, 1995; Martin, 1997).

The question mark after surrogacy indicates a question, a choice, as if surrogacy can be stopped if the "right" route is taken in the referendum. Heteroactivists' focus on the choice of sexual identities is clear and a key tenet of these arguments is that one can "choose" not to be gay. Because gay men cannot be trusted to make the right choice, the child needs to be protected from the predatory gay man. This creates an imperative to Vote No given that the gay men have not taken the correct route, and requiring the (heterosexual) voter to do the right thing, in order to avoid a certain sort of surrogacy. 
The image of the child and the risk of gay male parenting also hints at a much more sinister mythology about the predatory gay man as paedophile. The predatory gay man was a powerful (if often unnamed) trope in a range of everyday spaces that were informed by an:

'even-handed' media that gave a platform to the prospect of predatory gay men buying children to satisfy their paedophilic desires. ... [This media environment] framed as legitimate fears to be answered with a concerned tilt of the head and even-handed discussion - not just on the canvass, but in everyday interactions with total strangers. (Mulhall, 2015, np)

Subtly bringing the predatory gay man into the debate is crucial. The discursive tactic is to vilify gay men without suggesting that they are all "deviant," instead focusing on "prospects" and potentials. Humanising and linking lesbians and gay men into Irish families as sons, friends, work colleagues and others effectively countered the overt vilification of "deviant homosexuals" and required a different tactic than those used in the 1990s. Yet, these subtle and unsaid references are heard clearly by LGBT people and the furtive link to concerns regarding children is a powerful heteroactivist tactic (Webb \& Chonody, 2014). These suggestions draw from discourses about the free-floating foreign contagion of homosexuality and nestle in the anxieties regarding the threats posed to national borders, identities and sexualities (Conrad, 2001).

Heteroactivism operates distinctively in new sexual and gendered landscapes, where the "unnaturalness" in question is not explicitly linked to a deviant homosexual body who is unfit for society and who cannot be accepted as part of the nation. Instead, the focus is placed on "natural" procreation and genetics, which seeks to reassert heterosexuality as "normal," common sense and the unquestioned centre of the national imaginary. This labelling of "unnatural" desires and "immoralities" no longer holds sway as an argument in certain contexts, such as "modern Ireland."

She needs a mother for life, not just for nine months. Moving to unpack the gendered presumptions and associations embodied in Figure 1 enables us to explore the presences and absences in the reconstitution of "Who is Irish?" in a modern Ireland, by those seeking to recuperate a specific form of hegemonic heteronormativity. The power relations being defended link gender, family and genetic lineage: "She needs a mother for life, not just for nine months." Taking each phrase in turn serves to highlight how heteroactivist ideologies are (re)framing sexualities, genders and nations to reproduce heteronorms; norms that are brought into question through voting for same-sex marriage.

"She" discursively returns us to the image of the female child, one that is perhaps more vulnerable than a male child. However, focusing on the "she" also avoids engaging with the complicities of the Church in the sex abuse scandals, characterised by male-male sexual abuse. The "she" is important in the sexed contrast to the two male parents, and points to a lack of a mother as an appropriate female role model. In contrast to the gendered imagining of men as the protectors of a nation's children (Conrad, 2004), the threat to the heterosexual family of Ireland is a threat to its children. Men are seen as not only different from women and girls and ineffective in providing proper guidance to a female child or young woman, but also as predatory. The argument by heteroactivist organisations suggests that while single mothers can be accepted, it is only in very rare cases (death or similar) that fathers should be enabled to have children, especially female children, "alone." Essentialised genetic roots often underlie heteroactivist arguments, while here the supposedly fixed biological sex of woman/female renders men unfit parents without the presence of the mother. Echoing Nash's $(2005,2008)$ geographies of relatedness, exclusive models of Irish nation/ethnicity are layered within a heteronormative narrative of mother/family/ children produced through genetic heritage. This is implicit but powerful, as it lays claim to the common-sense territory of "real"/"proper" families.

The discursive underpinnings of "she" go beyond present dangers and hint at her role as a future mother for Ireland. As Ahmed (2006) notes, the reproduction of the other (in this case the male couple) challenges an ideal that creates nations for future generations. The futurity here develops through the child for generations and only reproduced "effectively" through "proper" (genetic) parenting which unquestioningly equates to an appropriate childhood experience. Heteroactivism is concerned for the future as it is constructed, or in their terms "destroyed," through present decisions. These protections go beyond women's bodies as needing protection from "fathers, husbands and the (national) state" (Mostov, 2000, p. 91), to specifically heteronormative protections formed through biological bonds that are linked to reproductive futures. In this way, the term "she" evokes the place of family based on and in heteronormative Irishness, as the cornerstone of present happiness and future possibilities not only for her but also for the nation.

"Needs" implores an impulse to protect, to provide for her, to cater for her "needs." The discourse seeks to reiterate the need for a specific, "proper" family form; it is something that she must have as she "needs" it. Without this need being fulfilled, her life will be incomplete, she will miss out on a central biological and essential "need," namely the connection to 
"a mother." It is not just "she" that needs it, however; the broader nation embodied through the child "needs" this vote, and as a consequence, so does the "common good." Same-sex marriage then threatens the foundations of the Irish nation through an "attack" on children, by failing to provide what they "need." It threatens the mother-daughter relationship required for the proper formation of the Irish family and the Irish state.

This relationship is different to sexual and gendering of nations or the focus on abortions, and instead offers glimpses into an understanding of femininities that cross between generations. These femininities rest on the bonds between a mother and a daughter, mobilising a specific form of kinship that is beyond contestation and rooted in biological imperatives. This symbolic power is not easily elided and echoes Martin's suggestion that "in nationalist Ireland women have almost exclusively borne the labour of representing the nation ... [with] material consequences for body self and nation" (1997, p. 67). It is not only the self but also the webs of relatedness based in bonds within the proper family that are necessary. These operate to the exclusion of those who would seek to remove the "need" for a mother, those who might be accused of "queer treasons" (Conrad, 2001).

"A mother" - the use of the singular in this discourse is important, implicitly suggesting the inadequacy of lesbian parenting. As Ryan, contends, Irish legal precedent suggests that while "one Irish mammy [is] firmly embedded in the bosom of the family home [and] is self-evidently integral to the common good ... the prospect of two women raising a child together falls outside the constitutional confines of family life" (2012, p. 425; Ryan-Flood, 2005). Lesbian parenting and lesbian mothers were rarely mentioned in the debates, but when they/we are, their/our children are seen as searching for a father figure in Danish sperm donors (as this is where the main European Sperm Banks are located, selling extensively to Ireland due to similar skin, eye and hair colours). Finding "real," genetic parentage in "other" places implies that these children are "only half" and therefore "not fully" Irish, reconstituting the genetic-place-kinship connectivities (Nash, 2005). Where Irish nationhood cannot be explicitly denied on the basis of sexuality, the reproduction of "half Irish" children reiterates that these are not "real" families, given an improper relatedness contests heteronormative genetic constructs of "real" Irishness. She does not need mothers; she needs $a$ mother.

Lesbian mothers are an almost invisible spectre, remaining hidden behind the dangers of "two married men," who represent an "attack" on the mother:

Even if a future court does not find that two married men have a right to have children through surrogacy, any Government which permits opposite-sex married couples to use surrogates will be bound by the Constitution to also allow two married men to use a surrogate, which once again is a deliberate attack on the child's right to a mother. (Mother and Fathers Matter Press Release, 2015)

While fathers were oft-mentioned in the Irish debate, as the above quote illustrates, references to men and families were more often referred to through the rights of "two married men." This gendered form of heteroactivism reflects more broadly the ideals of women and men in heteronormative relationships, and the patriarchal constructs of the nation that demonises non-hegemonic forms of heterosexual masculinities (Conrad, 2001). This was also apparent in visual representations: whereas other posters from both Mothers and Fathers Matter and also another key heteroactivist group, the Iona Institute, did include a mother and a father, there were no posters that specifically and emotively pointed to the absence of the father (and it is the absence of the mother, alongside the child's pensive look that is powerfully evoked in this poster). This reiterates the presumption that motherhood "unquestioningly" differentiates women's "experiences from those of men" (Holloway, 1999, p. 91), and the experiences of children raised by men compared with those raised by "mothers." Linking the image of the Irish child to surrogacy rather than broader fertility treatments not only points to a homosexual lack, but also to a desperation on the part of "predatory men" circling back to "defenceless" children that need to be guarded by "a mother" who protects her child. The forlorn figure becomes a defenceless and importantly a motherless child if same-sex marriage is allowed.

"For life" - this discursive ploy evokes a commitment, one that is lost to the motherless child. The ideal of the mother is based on sacrifice and a lifelong promise to her children. The question of whose life matters is answered evidently as the life of the child. It is not only women's bodies that continue to be used "to determine the moral, political and physical boundaries of the [Irish] Republic itself" (Martin, 2000, p. 66), but also their lives. The life of the mother should be subservient and sacrificed for the child, "unnatural desires" supressed to give the child the "best life" in a heterosexual family.

It is not just the ideal of the mother as a "reproducer of the nation" (Mostov, 2000) to be protected, it is also the longitudinal mother-daughter relationship. Mother-daughter relatedness is idealised as lasting a lifetime and as a perfect, loving relationship that is key to a child's (and adult's) success and happiness. The idealisation of this long-term relationship links into future generations and the assurance of "proper" sexual and gender development. One key area for those resisting 
sexual and gender equalities is ensuring the normative heterosexual and bi-gendered socialisation of children. The life she will lead depends on "a mother's" support and care that lasts. Without this lifeline, it is a "tragedy" that can lead not only to individual problems, but also broader national issues created through social breakdown. In heteroactivist discourses, children that refute gender and sexual norms are read as a "problem" to the moral fabric of society and the broader "common good." Thus, determining national moralities through Irish women's bodies extends beyond their individual bodily boundaries (Martin, 2000), within broader "proper" families, through mother-daughter relatedness towards an imagined idealised reproductive future (cf. Edelman, 2004).

"Not just" - the discourse of "not just" begins our return to women's bodies and the related connections between foetus-child-parent. As the harbinger of the social and moral state of the nation, biological and social parentage defines "not just" a woman, but the nation's "women." She is "a mother," and indeed "the mother." The needs of a foetus are equated to the needs of a child, biological needs interchangeable with social needs. Unquestioned here are the rights (and aspirations) of women; their relationship with the foetus and such rhetoric dismisses even the possibility of abortion.

Organisations who campaigned against same-sex marriage, such as the Iona Institute, are also "pro-life." Martin (2000), focusing on the abortion debates in the 1990s, argues that Irishness rooted in Catholicism, directly linked the preservation of the Irish nation to Irish women's bodies. Currently, in Ireland, the foetus is equal to the life of the mother within the 8th amendment of the Constitution of Ireland. When considering heteroactivism, linking control of women's bodies to both abortion and genetic parentage underpins the heteronormativities being campaigned for.

"For 9 months" - in Ireland, reproductive women's bodies have long been material and ideological battlegrounds (Conrad, 2004). The link to womb and uterus as women's bodies is clear, returning a woman to her embodiment, but more than this, it links this directly with a social role of "the mother." Breaking this link is an affront to the "natural order." While the messy materialities of bodies can be absent from discussions of same-sex marriage, except to note absence of adultery as a reason for annulment/divorce (Barker, 2006), the messy "unnatural" materialities of gay sex, and children brought into the world through reproductive technologies that break with biological relatedness, are core to heteroactivists' discourses. Focusing on the "natural order" that creates "proper families" and the common good based on reproductive sex between one man and one woman, normatively gendered, remains central to the explicit claims of these heteroactivist groups.

"For 9 months" also links back to discourses about dangerous gay men, but now focusing on women's bodies as "wombs for rent" by predatory gay men seeking children. Through this discourse, Irish heteroactivist groups attempted to align themselves with "feminists" who also protest the classed and racialised exploitation of women's bodies through surrogacy (see Nast, 2002). The heteroactivist focus on female bodies is conditioned by their anti-abortion and often patriarchal positions, such that these groups foreground the child rather than the woman. Here the 9 months is "for" the child. Irish heteroactivists place women on the front line of defending Ireland's morality as a nation through the spectre of abortion (Coulter, 1995; Martin, 1997, 2000), and reiterate the importance of protecting nations by protecting women's bodies from invasion by "foreign," in this case gay, men.

Finally, the "Vote No" with a heart in the first "o" indicates love. This was used on all the posters produced by Mothers and Fathers Matter. Its location indicates a specific form of love, a love for the figure of the child, for the children of Ireland who need protection through a "proper" family and a "real" mother. Locating the heart in the Vote rather than the No refuses a negativity, but more importantly, indicates an expression of love that might be associated with this poster and the campaign more broadly. It is seeking a heteronormative nation built on specific ideals of love, but also potentially through a love for a nation. As Ahmed notes with regard to white supremacy:

Making nation is tied to making love in the choice of the ideal other (different sex/same race), who can allow for the reproduction of the nation in the ideal form for future generations. (2006, p. 124)

The use of love to demonstrate a love for "us" as "the nation," in the face of the threat of "others," is apparent here. The others in this context are the predatory gay men, seeking "vulnerable (white) women" and "wombs for rent." This is contrasted with the love for the child and the nation, properly reproduced through heterosexual families and mother-daughter bonds that create a white Irish girl who can in turn continue the nation. Countering accusations of homophobia and hateful speech levelled against heteroactivists, the heart suggests hope. It makes a "no" vote one that is made with, and for, heteronormative love. It is also a vote for the common good of society, a common good that rejects surrogacy and twofather families. It is a "common good" that creates the same in terms of Irish nationhood, the same in racially, sexually and binary-gendered terms. The homosexual other is implicitly rejected by invoking moral society debates to create a specific Irish (hetero)sexualised nationhood, making gay men in particular less than, and other to, the Irish Mammy. 


\section{6 | CONCLUSION}

There have been extensive changes in the sexual constitution of Irishness from a nation that decriminalised gay sex in 1993, to a referendum that approved same-sex marriage in 2015. Although scholarship has considered the normalisations required of those accepted into the fold, the emergence of new resistances to LGBT equalities are rarely accounted for. In this paper, we have used a geographies of heteroactivism approach, which conceptualises (and names) a form of activism that seeks to recuperate hegemonic heteronormativities where sexual and gender rights are in place. Heteroactivism as an analytical lens enables the development of conceptualisations of why (and how) sexual and gender rights and equalities are resisted, and more broadly how hegemonic heteronormativities are being articulated (and what cannot be articulated) in order to recuperate them. Geographies of heteroactivism make it clear that these ideological processes are spatially specific and geographically nuanced, in part through the ways that discourses are constituted through national imaginings of belonging and idealised genders/sexualities.

Contestations regarding national identities and belonging are core to heteroactivists who see their role as protecting the "common good." Conversely, this also seeks to create a national imperative enacted through "responsible" citizens who protect vulnerable others. The image and text explored in this paper delineates key perspectives about Irishness through "family," gendered motherhood, and at the same time, the subtle rejection of gay men's families. The spectre of the (deviant and immoral) gay man remains unshakable. Moving from the direct vilification of homosexuality to more "compassionate" yet still resistive discourses, the nation as family, and Ireland as mother, are positioned as under threat through the figure of the Irish child. The innovation, visually and textually, is of two men raising not only a motherless Irish child, but one who was made "motherless" by design and enabled by the state. Webs of relatedness make the child an extension of the mother, and their childhood constituted through the choices of the nation. Thus, the sexuality-gender-nation-state nexus is recreated not only through man-woman, but also through man-woman-child in a configuration of heteronormativity as not only for the "common good" but also as meeting the "needs" of the figure of the child.

Scholars need to continue critical interrogations of heteroactivism, and look beyond the same-sex marriage battles to consider more broadly the (re)claiming of the "ideal citizen" who is heterosexual, normatively gendered and as such the proper and (only) viable "family." Conceptualising these movements and their manifestations is crucial if we are to understand contemporary gendered and sexual landscapes and develop nuanced geographical understandings of the nexus of nations-states-sexualities-genders. Therefore, not only do geographies need to engage with heteroactivism, but also critical work on heteroactivism needs to engage with geographical thinking.

\section{ACKNOWLEDGEMENTS}

The authors would like to thank Heather Maguire for her assistance in preparing this manuscript and her ongoing work on the larger project. We want to thank Dean Mizzi and Andrew McCarten for their research assistance. We would also like to thank the session audience at the Royal Geographical Society (with the Institute of British Geographers) 2016 conference for their insightful comments and thoughts. Finally, we are indebted to Joseph DeLappe, Gavin Brown and the reviewers whose constructive critical approach, engagement and suggestions have immeasurably strengthened the paper.

\section{ENDNOTES}

\footnotetext{
${ }^{1}$ Many thanks to Dr Miriam Smith (York University) for coining the term heteroactivism with us during our discussions about this research.

${ }^{2}$ The focus of this paper is on lesbian, gay, bisexual and trans rights, and same-sex marriage. Sexual and gender rights are of course more than this. Although it is beyond the scope of this paper to address these areas, we hope it provides a way of exploring contemporary resistances to broader sexual and gender rights through discourses of heteroactivism. In the Irish context, the "fallen woman" narrative is far less apparent in resisting abortion rights, focusing instead on the life of the foetus as a child.

${ }^{3}$ We see this as an important area of research development that could build on the scholarship in this paper.

${ }^{4}$ Recent scholarship also empirically examines civil partnerships and same-sex marriages. This body of work details the complexities of same-sex marriage for those who are engaging with it, or agitating for it (e.g., Neary, 2016; Peel \& Harding, 2008).

${ }^{5}$ The Protection of Life During Pregnancy Act (2013) allows for abortion if there is an immediate and significant risk to a woman's life, including in relation to suicide. The suicide risk is assessed by six doctors. There is no right to abortion where there is a foetal abnormality (Abortion Rights Campaign, 2015).

${ }^{6}$ This poster was produced by the heteroactivist organisation "Mothers and Fathers Matter," a core organisation in the Irish Vote No campaign resisting the redefinition of marriage.
} 
${ }^{7}$ There was some controversy over the removal and defacing of No posters, particularly in the Dublin area, as people protested against their homophobic content (McNamee, 2015).

${ }^{8}$ This was not the only poster in the campaign that caused controversy. Another poster used an Australian couple who came out in favour of same-sex marriage (see Kennedy, 2015). The problematic use of a non-Irish couple feeds into the discourses discussed below.

${ }^{9}$ There is much to be said on the construction of the child in heteroactivist discourses, and particularly the innocent, gender and sexual normative child who is corrupted by queer influences. This is beyond the scope of this paper. However, see Edelman (2004) and Stockton (2009) for a discussion of the figure of the child and the child as always queer and needing civilising. We focus here on the parenting and family relationships reconstituted through the visual and discursive idealised representations of the relationship between mothers and children.

${ }^{10}$ This was despite surrogacy rights being dealt with under separate and unrelated legislation. The Vote No campaigns did, at certain points, acknowledge that the legal changes did not directly pertain to parenting.

\section{ORCID}

Kath Browne (iD http://orcid.org/0000-0002-5816-226X

Andrew Gorman-Murray $\mathbb{D}_{\text {iD }}$ htp://orcid.org/0000-0001-7479-8172

\section{REFERENCES}

Abortion Rights Campaign (2015). 5 facts about abortion in Ireland. Retrieved from http://www.abortionrightscampaign.ie/2015/06/12/5facts/sthash.tX924mp3.dpuf

ACME (2017). Queer semiotics [Special Issue]. ACME, 16, 362-606.

Ahmed, S. (2006). The nonperformativity of antiracism. Meridians: Feminism, Race, Transnationalism, 7, 104-126. https://doi.org/10.1353/mer. 2007.0000

Andersen, R., \& Fetner, T. (2008). Economic inequality and intolerance: Attitudes toward homosexuality in 35 democracies. American Journal of Political Science, 52, 942-958. https://doi.org/10.1111/j.1540-5907.2008.00352.x

Barker, N. (2006). Sex and the civil partnership act: The future of (non) conjugality? Feminist Legal Studies, 14, 241-259. https://doi.org/10. 1007/s10691-006-9029-7

Bell, D., \& Binnie, J. (2000). The sexual citizen: Queer politics and beyond. Cambridge, UK: Polity.

Bell, D., \& Valentine, G. (Eds.) (1995). Mapping desire: Geographies of sexualities. London, UK: Routledge.

Brown, G., \& Browne, K. (2016). The Routledge research companion to geographies of sex and sexualities. London, UK: Routledge.

Browne, K., \& Nash, C. J. (2014). Resisting LGBT rights where "we have won": Canada and Great Britain. Journal of Human Rights, 13, 322336. https://doi.org/10.1080/14754835.2014.923754

Burack, C. (2014). The politics of a praying nation: The presidential prayer team and Christian right sexual morality. Journal of Religion and Popular Culture, 26, 215-229. https://doi.org/10.3138/jrpc.26.2.215

Burack, C., \& Josephson, J. J. (2005). Origin stories: Same-sex sexuality and Christian Right politics. Culture and Religion, 6, 369-392. https:// doi.org/10.1080/01438300500460435

Burack, C., \& Wilson, A. R. (2009). Constructing Christian right enemies and allies: US, UK and Eastern Europe. In P. Scott (Ed.), Remoralizing Britain: Studies in religion and political Culture (pp. 136-155). London, UK: Continuum.

Connolly, L. (2014). The 'Irish' family. London, UK: Routledge.

Conrad, K. (2001). Queer treasons: Homosexuality and Irish national identity. Cultural Studies, 15, 124-137. https://doi.org/10.1080/ 09502380010012630

Conrad, K. (2004). Locked in the family cell: Gender, sexuality, and political agency in Irish national discourse. Madison, WI: University of Wisconsin Press.

Cooper, D. (2015). Bringing the state up conceptually: Forging a body politics through anti-gay Christian refusal. Feminist Theory, 16 , 87-107. https://doi.org/10.1177/1464700114562536

Coulter, C. (1995). Feminism, nationalism, and the heritage of the Enlightenment. In T. Foley, L. Pilkington, S. Ryder, \& E. Tilley (Eds.), Gender and colonialism. Galway, Ireland: Galway University Press.

Crowley, U., \& Kitchin, R. (2008). Producing 'decent girls': Governmentality and the moral geographies of sexual conduct in Ireland (19221937). Gender, Place and Culture, 15, 355-372. https://doi.org/10.1080/09663690802155553

Dowland, S. (2015). Family values and the rise of the Christian right. Philadelphia, PA: University of Pennsylvania Press.

Edelman, L. (2004). No future: Queer theory and the death drive. Durham, NC: Duke University Press.

Entertainmentwise (2015). These 'No' Vote posters in Irish same sex marriage referendum have been causing complaints. Retrieved from https:// www.entertainmentwise.com/same-sex-marriage-vote-ireland-posters/

Greene, S. M. (1994). Growing up Irish: Development in context. The Irish Journal of Psychology, 15, 354-371. https://doi.org/10.1080/ 03033910.1994 .10558016

Harding, R., \& Peel, E. (2006). "We do"? International perspectives on equality, legality and same-sex relationships. Lesbian and Gay Psychology Review, 7, 123-140. 
Holloway, S. (1999). Reproducing motherhood. In N. Laurie, C. Dwyer, S. Holloway, \& F. Smith (Eds.), Geographies of new femininities (pp. 91-112). New York, NY: Longman.

Hubbard, P. (2006). City. London, UK: Routledge.

Johnson, P., \& Vanderbeck, R. (2014). Law, religion and homosexuality. London, UK: Routledge.

Kearns, G. (2004). Mother Ireland and the revolutionary sisters. Cultural Geographies, 11, 443-467. https://doi.org/10.1191/1474474004eu315oa

Kearns, D. (2015, April 23). Families hit out over 'No' campaign poster criticising surrogacy. Irish Independent. Retrieved from https://www.in dependent.ie/irish-news/families-hit-out-over-no-campaign-poster-criticising-surrogacy-31165662.html

Kennedy, J. (2015, May 7). Couple on vote no posters: 'We received no money for that photo and we would vote Yes for marriage equality'. Irish Independent. Retrieved from https://www.independent.ie/irish-news/irish-abroad/couple-on-vote-no-posters-we-received-no-money-for-tha t-photo-and-we-would-vote-yes-for-marriage-equality-31203153.html

Kuhar, R., \& Paternotte, D. (2017). Anti-gender campaigns in Europe: Mobilising against equality. London, UK: Rowman and Littlefield.

Maddox, M. (2014). Right-wing Christian intervention in a naïve polity: The Australian Christian lobby. Political Theology, 15, 132-150. https://doi.org/10.1179/1462317X13Z.00000000071

Martin, A. K. (1997). The practice of identity and an Irish sense of place. Gender, Place and Culture: A Journal of Feminist Geography, 4, 89114. https://doi.org/10.1080/09663699725512

Martin, A. K. (2000). Transnationalism, bodies and abortion in late twentieth-century Ireland. In T. Mayer (Ed.), Gender ironies of nationalism: Sexing the nation (pp. 65-86). London, UK: Routledge.

Mayer, T. (2000). Gender ironies of nationalism: Sexing the nation. London, UK: Routledge.

McAuliffe, M., \& Kennedy, S. (2017). Defending catholic Ireland. In R. Kuhar, \& D. Paternotte (Eds.), Anti-gender campaigns in Europe: Mobilizing against equality. London, UK: Rowman and Littlefield.

McNamee, M. S. (2015, April 29). The No campaign's posters keep getting defaced and ripped down. The Journal. Retrieved from http://www. thejournal.ie/no-campaign-posters-defaced-down-damaged-2073076-Apr2015/

McVeigh, R. (2010). United in whiteness? Irishness, Europeannness and the emergence of a 'White Europe' policy. European Studies: A Journal of European Culture, History and Politics, 28, 251-278. https://doi.org/10.1163/9789042030541_012

Meaney, G. (1994). Sex and nation: Women in Irish culture and politics, a dozen lips. Dublin, Ireland: Attic Press.

Mostov, J. (2000). Politics of national identity in the former Yugoslavia. In T. Mayer (Ed.), Gender ironies of nationalism: Sexing the nation (pp. 41-59). London, UK: Routledge.

Mothers and Fathers Matter (2015). Marriage referendum no posters focus on the key areas of public debate. Retrieved from https://mothersa ndfathersmatter.org/marriage-referendum-no-posters-focus-on-the-key-areas-of-public-debate/

Mulhall, A. (2015, June 20). The Republic of Love: On the complex achievement of the same-sex marriage referendum in Ireland. Bully Bloggers. Retrieved from https://bullybloggers.wordpress.com/2015/06/20/the-republic-of-love/

Nash, C. (1993). "Embodying the Nation”: The west of Ireland landscape and Irish Identity. In B. O’Connor, \& M. Cronin (Eds.), Tourism in Ireland: A critical analysis (pp. 86-112). Cork, Ireland: Cork University Press.

Nash, C. (1994). Remapping the body/land: New cartographies of identity, gender, and landscape in Ireland. In A. Blunt, \& G. Rose (Eds.), Writing women and space: Colonial and postcolonial geographies (pp. 227-250). New York, NY: Guilford Press.

Nash, C. (1997). Embodied Irishness: Gender, sexuality and Irish identities. In B. Graham (Ed.), In search of Ireland: A cultural geography. London, UK: Routledge.

Nash, C. (2005). Geographies of relatedness. Transactions of the Institute of British Geographers, 30, 449-462. https://doi.org/10.1111/j.14755661.2005.00178.x

Nash, C. (2008). Of Irish descent: Origin stories, genealogy, and The politics of belonging. Syracuse, NY: Syracuse University Press.

Nash, C. J., \& Browne, K. (2015). Best for society? Transnational opposition to sexual and gender equalities in Canada and Great Britain. Gender, Place and Culture, 22, 561-577. https://doi.org/10.1080/0966369X.2014.885893

Nast, H. J. (2002). Queer patriarchies, queer racisms, international. Antipode, 34, 874-909. https://doi.org/10.1111/1467-8330.00281

Neary, A. (2016). Civil Partnership and marriage: LGBT-Q political pragmatism and the normalization imperative. Sexualities, $19,757-779$. https://doi.org/10.1177/1363460715616943

Negra, D. (2014). Adjusting men and abiding mammies: Gendering the recession in Ireland. In C. Holohan, \& T. Tracy (Eds.), Masculinity and Irish popular culture (pp. 223-237). London, UK: Palgrave Macmillan.

O'Caoimh, D. (2015, April 23). Please vote YES to marriage equality in Ireland. Something Odd. Retrieved from https://odd.blog/2015/04/ 23/please-vote-yes-to-marriage-equality-in-ireland/

Peel, E., \& Harding, R. (2008). Editorial introduction: Recognizing and celebrating same-sex relationships: Beyond the normative debate. Sexualities, 11, 659-666. https://doi.org/10.1177/1363460708096911

Puar, J. K. (2007). Terrorist assemblages: Homonationalism in queer times. Durham, NC: Duke University Press.

Rauch, J. (2004). Gay marriage: Why it is good for gays, good for straights, and good for America. New York, NY: Times Books.

Rayside, D., \& Wilcox, C. (Eds.) (2011). Faith, politics, and sexual diversity in Canada and the United States. Vancouver, BC: UBC Press.

Referendum Results (2015). Referendum 2015. Retrieved from http://www.referendum.ie/results-summary.php?ref=10)

Richardson, D. (2004). Locating sexualities: From here to normality. Sexualities, 7, 391-411. https://doi.org/10.1177/1363460704047059

Richardson, D. (2005). Desiring sameness? The rise of a neoliberal politics of normalisation. Antipode, 37, 515-535. https://doi.org/10.1111/ j.0066-4812.2005.00509.x

Robertson, J., \& McDaniel, C. (2010). Themes of contemporary art. New York, NY: Oxford University Press. 
Rose, G. (2016). Visual methodologies: An introduction to researching with visual materials. London, UK: Sage.

Ryan, F. W. (2012). Are two Irish mammies (even) better than one? Heteronormativity, homosexuality and the 1937 constitution. In E. Carolan (Ed.), The constitution of Ireland: Perspectives and prospects. London, UK: Bloomsbury Professional.

Ryan, F. W. (2015). Same-sex couples and the Marriage Act 2015: Implications for practice. Retrieved from https://ssrn.com/abstract=2700626

Ryan-Flood, R. (2005). Contested heteronormativities: Discourses of fatherhood among lesbian parents in Sweden and Ireland. Sexualities, 8, 189-204. https://doi.org/10.1177/1363460705050854

Siegel, S. (2017). Marriage equality and rightwing populism in the EU: An intimate connection. Paper presented at the Jean Monnet Center of Excellence Faculty Research Workshop, Marriage Equality in Advanced Industrialized Democracies, University of Pittsburgh.

Silvera, A. (2015, May 21). Marriage is not equality: Thoughts on \#MarRef from a worried radical queer. Feminist Ire. Retrieved from https:// feministire.com/2015/05/21/marriage-is-not-equality-thoughts-on-marref-from-a-worried-radical-queer/

Stevens, L., Brown, S., \& Maclaran, P. (2000). Gender, nationality and cultural representations of Ireland: An Irish woman's place? European Journal of Women's Studies, 7, 405-421. https://doi.org/10.1177/135050680000700412

Stockton, K. B. (2009). The queer child, or growing sideways in the Twentieth Century. Durham, NC: Duke University Press.

Stychin, C. F. (2009). Faith in the future: Sexuality, religion and the public sphere. Oxford Journal of Legal Studies, 29, 729-755. https://doi.org/ 10.1093/ojls/gqp016

Thapar-Björkert, S., \& Ryan, L. (2002). Mother India/Mother Ireland: Comparative gendered dialogues of colonialism and nationalism in the early 20th century. Women's Studies International Forum, 25, 301-313.

Todd, N. R., \& Ong, K. S. (2012). Political and theological orientation as moderators for the association between religious attendance and attitudes toward gay marriage for White Christians. Psychology of Religion and Spirituality, 4, 56-70. https://doi.org/10.1037/a0025142

Tremblay, M., Paternotte, D., \& Johnson, C. (Eds.) (2011). The lesbian and gay movement and the state: Comparative insights into a transformed relationship. Burlington, VT: Ashgate.

Walter, B. (2001). Outsiders inside: Whiteness, place, and Irish women. London, UK: Routledge.

Webb, S. N., \& Chonody, J. (2014). Heterosexual attitudes toward same-sex marriage: The influence of attitudes toward same-sex parenting. Journal of GLBT Family Studies, 10, 404-421. https://doi.org/10.1080/1550428X.2013.832644

Wilkinson, E. (2013). Learning to love again: 'Broken families', citizenship and the state promotion of coupledom. Geoforum, 49, $206-213$. https://doi.org/10.1016/j.geoforum.2013.02.012

Wills, C. (2001). Women, domesticity and the family: Recent feminist work in Irish cultural studies. Cultural Studies, 15, 33-57. https://doi.org/ $10.1080 / 09502380010006745$

Zebracki, M., \& Milani, T. (2017). Critical geographical queer semiotics. ACME: An International Journal for Critical Geographies, 16, 427439.

How to cite this article: Browne K, Nash CJ, Gorman-Murray A. Geographies of heteroactivism: Resisting sexual rights in the reconstitution of Irish nationhood. Trans Inst Br Geogr. 2018;43:526-539. https://doi.org/ $\underline{10.1111 / \operatorname{tran} .12255}$ 